\title{
Glucose-6-Phosphate Isomerase
}

National Cancer Institute

\section{Source}

National Cancer Institute. Glucose-6-Phosphate Isomerase. NCI Thesaurus. Code

C17428.

Glucose-6-phosphate isomerase ( $558 \mathrm{aa}, \sim 63 \mathrm{kDa}$ ) is encoded by the human GPI gene.

This protein is involved in glycolysis in as a cytoplasmic homodimer and has a secreted

monomeric form that either exhibits cytokine activity or can function as a neurotrophic factor. 